\title{
Temperature and moisture effects on greenhouse gas emissions from deep active-layer boreal soils
}

\author{
Ben Bond-Lamberty ${ }^{1}$, A. Peyton Smith $^{2}$, and Vanessa Bailey ${ }^{2}$ \\ ${ }^{1}$ Joint Global Change Research Institute, DOE Pacific Northwest National Laboratory, College Park, MD, USA \\ ${ }^{2}$ Biological Sciences Division, Pacific Northwest National Laboratory, Richland, WA, USA \\ Correspondence to: Ben Bond-Lamberty (bondlamberty@pnnl.gov)
}

Received: 1 June 2016 - Published in Biogeosciences Discuss.: 2 June 2016

Revised: 23 November 2016 - Accepted: 9 December 2016 - Published: 21 December 2016

\begin{abstract}
Rapid climatic changes, rising air temperatures, and increased fires are expected to drive permafrost degradation and alter soil carbon (C) cycling in many high-latitude ecosystems. How these soils will respond to changes in their temperature, moisture, and overlying vegetation is uncertain but critical to understand given the large soil $\mathrm{C}$ stocks in these regions. We used a laboratory experiment to examine how temperature and moisture control $\mathrm{CO}_{2}$ and $\mathrm{CH}_{4}$ emissions from mineral soils sampled from the bottom of the annual active layer, i.e., directly above permafrost, in an Alaskan boreal forest. Gas emissions from 30 cores, subjected to two temperatures and either field moisture conditions or experimental drought, were tracked over a 100-day incubation; we also measured a variety of physical and chemical characteristics of the cores. Gravimetric water content was $0.31 \pm 0.12$ (unitless) at the beginning of the incubation; cores at field moisture were unchanged at the end, but drought cores had declined to $0.06 \pm 0.04$. Daily $\mathrm{CO}_{2}$ fluxes were positively correlated with incubation chamber temperature, core water content, and percent soil nitrogen. They also had a temperature sensitivity $\left(Q_{10}\right)$ of 1.3 and 1.9 for the field moisture and drought treatments, respectively. Daily $\mathrm{CH}_{4}$ emissions were most strongly correlated with percent nitrogen, but neither temperature nor water content was a significant first-order predictor of $\mathrm{CH}_{4}$ fluxes. The cumulative production of $\mathrm{C}$ from $\mathrm{CO}_{2}$ was over 6 orders of magnitude higher than that from $\mathrm{CH}_{4}$; cumulative $\mathrm{CO}_{2}$ was correlated with incubation temperature and moisture treatment, with drought cores producing 52-73\% lower C. Cumulative $\mathrm{CH}_{4}$ production was unaffected by any treatment. These results suggest that deep active-layer soils may be sensitive to changes in soil moisture under aerobic conditions, a critical factor as discontinu-
\end{abstract}

ous permafrost thaws in interior Alaska. Deep but unfrozen high-latitude soils have been shown to be strongly affected by long-term experimental warming, and these results provide insight into their future dynamics and feedback potential with future climate change.

\section{Introduction}

High-latitude ecosystems are being subjected to rapid changes in climate (IPCC, 2013) and increases in fire frequency and intensity (Kasischke et al., 2010), notably in northwestern North America and Alaska (Hinzman et al., 2005; Ju and Masek, 2016). This will have a wide variety of ecosystem effects (Alexander and Mack, 2016): in particular, rising temperatures and increasing fire will likely result in changes in soil temperature and permafrost degradation (Pastick et al., 2015; Zhang et al., 2015; Genet et al., 2013; Helbig et al., 2016), with subsequent hydrology changes that will influence soil greenhouse gas (GHG) fluxes to the atmosphere (Schädel et al., 2014). Such fluxes are a large component of the global $\mathrm{C}$ cycle and could result in a significant and positive climate feedback (Treat et al., 2015; Koven et al., 2011; Schaefer et al., 2014).

The magnitude, timing, and form - in particular as methane $\left(\mathrm{CH}_{4}\right)$ or carbon dioxide $\left(\mathrm{CO}_{2}\right)$ - of any such feedback remain highly uncertain (Schuur et al., 2015). While northern soils hold enormous quantities of potentially mineralizable soil organic carbon (SOC) (Hugelius et al., 2014), vegetation and succession dynamics (for example, thermal insulation by mosses) promote permafrost resilience to even large temperature changes (Jorgenson et al., 2010; Turetsky 
et al., 2012). Vegetation type also influences SOC quality and quantity, with microbial communities (Högberg et al., 2007), soil respiration (Raich and Tufekcioglu, 2000), and SOC all linked to aboveground factors such as woody vs. nonwoody stems, deciduous vs. evergreen canopies, and the presence of nitrogen-fixing plants. A number of factors may however disrupt these feedbacks between vegetation type, ground cover, permafrost, and SOC stability. Climate changes, in particular regional warming and drying, cause vegetation stress $(\mathrm{Ju}$ and Masek, 2016; Barber et al., 2000) and increased mortality. Conversely, increasing plant productivity in some regions can stimulate the decomposition of older SOC (Hartley et al., 2012). Climate also drives fire regime changes, and ecosystem disruption is particularly likely after intense fires (Johnstone et al., 2010; Genet et al., 2013). Even without disturbance, the stability of SOC is highly uncertain since it depends on soil temperature and moisture, the ages of and ratio between the carbon $(\mathrm{C})$ and nitrogen $(\mathrm{N})$ pools (Weiss et al., 2015; Karhu et al., 2014), and its protection (whether by organomineral sorption, chemical lability, or physical location) from capable microorganisms, enzymes, and resources (Bailey et al., 2012; Schmidt et al., 2011).

Temperature and moisture typically have strong and often interactive influences on soil GHG emissions. Laboratory incubations, field observations, and metanalyses have documented changing GHG fluxes with rising temperature (Olefeldt et al., 2013; Davidson and Janssens, 2006; Hashimoto et al., 2015; Treat et al., 2015). GHG responses to wetting and thawing dynamics exhibit substantial variability between studies, probably due to differences in soil type, antecedent conditions, phase changes, experimental protocols, etc. (Kim et al., 2012). The common anaerobic conditions following permafrost thaw are expected to lower $\mathrm{CO}_{2}$ emissions but increase those of $\mathrm{CH}_{4}$ (Treat et al., 2015, 2014), but emissions from aerobic soils will likely dominate the permafrost C feedback (Schädel et al., 2016). Decadal warming and drying trends in Alaska (Bieniek et al., 2014) thus seem likely to increase GHG emissions from soils, and laboratory incubation experiments are critical in understanding these dynamics (Elberling et al., 2013).

Most previous studies have focused on surface soils or permafrost soils, neglecting deep active-layer soils that were identified as subject to strong effects from a 2-decade warming experiment in the Alaskan Arctic (Sistla et al., 2013). Such deeper soils have particular characteristics distinguishing them from both shallow active-layer soils and underlying permafrost: they are most affected by interannual variability in thaw depth, potentially flipping the $\mathrm{C}$ source-sink status of entire ecosystems (Goulden et al., 1998; Harden et al., 2012); they are subject to distinctive freeze-thaw, cryoturbation, and microbial dynamics, which are likely to change their sensitivity to climate change and feedback potential (Schuur et al., 2008); and they are known to pose particular problems for accurate modeling of high-latitude carbon dynamics (Nicolsky et al., 2007). These soils are likely to be a highly important contributor to future climate feedbacks, with modeling studies suggesting that one-third of 21st century climate-induced carbon loss may originate from seasonally frozen soil carbon (Koven et al., 2015).

The goal of this study was to examine how temperature and moisture control GHG $\left(\mathrm{CO}_{2}\right.$ and $\left.\mathrm{CH}_{4}\right)$ emissions from soils sampled from the bottom of the annual active layer i.e., directly above permafrost - in an Alaskan boreal forest. We also aimed to characterize the chemical and structural properties of these soils following a 100-day incubation at different temperatures, subjecting some cores to drying treatments. We hypothesized that (i) $\mathrm{CO}_{2}$ would be the dominant pathway for $\mathrm{C}$ loss in these largely aerobic soils; (ii) soils maintained at field moisture and high $\left(20^{\circ} \mathrm{C}\right)$ temperature would lose more $\mathrm{C}-\mathrm{CO}_{2}$ than cores incubated at $4{ }^{\circ} \mathrm{C}$, due to increased aerobic and anaerobic microbial activity; and (iii) core $\mathrm{CH}_{4}$ fluxes would be small and sensitive only to temperature, as no anaerobic conditions were imposed on the cores.

\section{Methods}

\subsection{Field sampling}

The field component of this research took place in CaribouPoker Creeks Research Watershed (CPCRW), part of the Bonanza Creek LTER (http://www.lter.uaf.edu/research/ study-sites-cpcrw). CPCRW is located in the Yukon-Tanana Uplands northeast of Fairbanks, AK, a part of the boreal forest that has seen strong increases in air temperature and forest browning (Ju and Masek, 2016) over several decades. Annual average air temperature is $-2.5^{\circ} \mathrm{C}$, and annual average precipitation $400 \mathrm{~mm}$ (Petrone et al., 2006). The watershed's lowlands and north-facing slopes are dominated by black spruce (Picea mariana (Mill.) BSP), feathermoss (Pleurozium schreberi and others), and Sphagnum spp.; the drier southern slopes tend to be deciduous with a mixture of trembling aspen (Populus tremuloides Michx.), Alaska paper birch (Betula neoalaskana), and patches of alder (Alnus crispa).

We sampled soils from a southeastern slope $\left(65.1620^{\circ} \mathrm{N}\right.$, $147.4874^{\circ} \mathrm{W}$ ) at $\mathrm{CPCRW}$, in a $60 \mathrm{~m}$ transition zone between lowland Picea mariana and upland Betula neoalaskana, with significant white spruce (Picea glauca) presence as well. Stand density in this transition zone was $4060 \pm 2310$ trees ha $^{-1}$, with a basal area of $27.9 \pm 7.0 \mathrm{~m}^{2} \mathrm{ha}^{-1}$. The forest was at least 90 years old (see Morishita et al., 2014) according to tree cores taken at the base of several of the largest white spruce. The soil is characterized as a poorly drained silt loam, and on average had $\sim 20 \mathrm{~cm}$ of organic material over the mineral soil.

On 3-5 August 2015, 39 soil cores, each $30 \mathrm{~cm}$ high by $7.5 \mathrm{~cm}$ wide, were taken using a soil recovery augur (AMS Inc., American Falls, ID). We sampled from the bottom 
(within 0-2 cm of permafrost) of the active layer, which averaged $80 \mathrm{~cm}$ depth. Sample points were randomly located in the transition zone described above and separated by $2-5 \mathrm{~m}$. Cores were kept cool in the field before being packed in dry ice and shipped to Richland, WA, within $48-72 \mathrm{~h}$ of collection.

\subsection{Laboratory incubation}

In the lab, the soil cores were stored at $4{ }^{\circ} \mathrm{C}$ for several days until they were weighed and prepared for incubation. At that point (11-12 August 2015), three fragmented or otherwise damaged cores were discarded, and the remaining cores were randomly assigned to one of six groups $(\mathrm{N}=6$ in each group). These included two incubation temperatures of 4 and $20^{\circ} \mathrm{C}$, following the protocol of a number of previous boreal incubation studies (Treat et al., 2015). Within each temperature there were two moisture treatments: one in which soil moisture was maintained at field conditions ( $\sim 28 \%$ moisture by volume), and a drought treatment in which no water was added and cores were allowed to dry down to $\sim 5 \%$ moisture by volume. The fifth group was a $20^{\circ} \mathrm{C}$ "controlled drought" one, in which water was added so that the cores' moisture status would closely match those of the $4{ }^{\circ} \mathrm{C}$ "drought" cores, which we anticipated would dry more slowly than their $20^{\circ} \mathrm{C}$ counterparts. The final six-core group was used for destructive, pre-incubation measurements including moisture content, $\mathrm{pH}$, soil carbon and nitrogen, and bulk density. Subsamples were collected and stored at $-20^{\circ} \mathrm{C}$ for dissolved organic carbon measurements or air dried for soil C and $\mathrm{N}$ (see below).

On 18 August 2015 cores were placed into one of two growth chambers (Conviron Control Systems BDW80, Winnipeg, Canada) maintained at 4 and $20^{\circ} \mathrm{C}$ temperatures and $70 \%$ relative humidity and allowed to equilibrate for 2 weeks. Starting on 31 August 2015 we measured the cores' mass and GHG emissions four times in the first week, then twice per week for the first month, and then once per week for the rest of the 100-day incubation. Throughout the incubation, cores had a $200 \mu \mathrm{m}$ mesh screen fit to the base and were mounted on porous ceramic plates (Soil Moisture Equipment Corp., Santa Barbara, CA, USA) so that when the plates were placed in contact with water, water would move up into the cores via capillary action. The drought cores were mounted on dry plates but were not allowed to drop below $5 \%$ water content. After each flux measurement, cores received additional wetting from the top to maintain their desired water status.

For each measurement, a six-core treatment group was connected to a Picarro A0311 multiplexer that was in turn connected to a Picarro G2301 GHG Analyzer (Picarro Inc., Santa Clara, CA, USA). Dry $\mathrm{CH}_{4}$ and $\mathrm{CO}_{2}$ concentrations were monitored for $2 \mathrm{~min}$, and this was repeated two to three times before moving on to a new treatment group. Cores were weighed immediately after gas measurements. Ambient air was measured between treatment groups and before starting measurements in a chamber as a check on ambient $\mathrm{CO}_{2}$ conditions and instrument stability.

The incubation experiment concluded on 9 December 2015, following the final $\mathrm{CO}_{2}$ and $\mathrm{CH}_{4}$ readings. Each soil core was maintained at the treatment-dependent temperature and moisture content (by mass) until removed for destructive sampling on 14-18 December 2015. Subsamples were collected and composited throughout each soil core for dissolved organic carbon analysis $(110 \pm 24 \mathrm{~g}$ dry mass equivalent) and dry-mass calculations ( $\sim 28 \mathrm{~g}$ each). The remaining core material was air-dried and separated into particles $(>2 \mathrm{~mm}$ diameter) and soil $(\leq 2 \mathrm{~mm})$ using a US Standard Test Sieve No. 10 (Fisherbrand, Pittsburg, PA, USA). The dry mass and volume of soil were used in calculations of gravimetric and volumetric soil moisture content, respectively (Gardner, 1986). Soil volume was calculated as the total core volume minus the volume of particles $>2 \mathrm{~mm}$ diameter, with the latter determined by water displacement. Airdried soil and subsamples stored at $-20^{\circ} \mathrm{C}$ were sent to the Agricultural and Environmental Services Laboratory at the University of Georgia Extension in February 2016 for total $\mathrm{C}, \mathrm{N}$, and dissolved organic carbon (DOC) testing. Samples were combusted in an oxygen atmosphere at $1350^{\circ} \mathrm{C}$ and measured for gaseous $\mathrm{C}$ and $\mathrm{N}$ using an Elementar Vario Max CNS (Langenselbold, Germany). DOC was measured using a Shimadzu 5000 TOC Analyzer (Columbia, Maryland, USA).

\subsection{Data and statistical analysis}

For each measurement of each sample throughout the 100day incubation (i.e., each gas, core, and date and time), we used the rise in gas concentrations to calculate a flux rate in $\mathrm{ppm} \mathrm{s}^{-1}\left(\mathrm{CO}_{2}\right)$ or $\mathrm{ppb} \mathrm{s}^{-1}\left(\mathrm{CH}_{4}\right)$, a linear rate of change $(\delta c / \delta t)$ based on the concentration rise from a minimum (up to $10 \mathrm{~s}$ after measurement began) to a maximum (at 10 $45 \mathrm{~s})$. Each core's respiration flux $(F)$ was then calculated as $F=\frac{\delta c}{\delta t} \frac{V}{M} \frac{P_{\mathrm{a}}}{\mathrm{RT}}$, where $V$ is the core-specific system volume, $M$ the core dry mass as determined at the end of the incubation, $P_{\mathrm{a}}$ the atmospheric pressure $(101 \mathrm{kPa}$, the incubation chambers were $\sim 120 \mathrm{~m}$ a.s.1.), $R$ the universal gas constant $\left(8.3 \times 10^{-3} \mathrm{~m}^{3} \mathrm{kPa} \mathrm{mol}^{-1} \mathrm{~K}^{-1}\right)$, and $T$ the chamber air temperature $(\mathrm{K})$ at time of measurement. The final respiration rate was expressed on a soil $\mathrm{C}$ basis $(\mu \mathrm{g}$ or $\mathrm{ng} \mathrm{Cg} \mathrm{C}{ }^{-1}$ day $^{-1}$ ).

Anomalous data were excluded based on their gas fluxes being more than 5 (for $\mathrm{CO}_{2}$ ) or 10 (for $\mathrm{CH}_{4}$ ) mean absolute deviations (Davies and Gather, 1993) from the treatment mean within a 10-day period, for a given treatment and temperature. We excluded 172 of $2686(6.4 \%)$ measurements for this reason. If the coefficient of variability $(\mathrm{CV})$ of fluxes from any core on a single day exceeded $140 \%$, a value chosen based on the distribution of CVs across all cores, the entire core was excluded for that day (90 data points, $3.4 \%$ ). Other data $(4.8 \%)$ were removed because of known instru- 
ment problems, e.g., the analyzer was left running after leaving a chamber. The final number of valid flux samples from the 100-day incubation was 2198.

The effects of temperature, gravimetric water content, percent $\mathrm{C}$, percent $\mathrm{N}$, and DOC concentration on instantaneous gas fluxes were evaluated using a linear mixed-effect model fit by the $\mathrm{R}$ function lme in the $\mathrm{R}$ "nlme" package, version 3.1.128. Because the dependent variable $\left(\mathrm{CO}_{2}\right.$ or $\mathrm{CH}_{4}$ flux) was non-normally distributed, it was transformed using a natural-logarithm $\left(+0.1 \mu \mathrm{g} \mathrm{Cg} \mathrm{C}^{-1}\right.$ day $^{-1}$ to ensure all positive fluxes, following Treat et al., 2015) transformation. Soil core was treated as a random effect in the model. We then performed stepwise model selection by Akaike's information criterion (AIC) using the stepAIC function in the R "MASS" package, version 7.3.45. A linear mixed-effect model was also used to evaluate the effect of treatment on core water content.

Cumulative respiration for each core and gas was calculated by linearly interpolating flux rates between measurement dates and summing respired $\mathrm{C}$ over the entire incubation. The effect of temperature and treatment (drought, controlled drought, or field moisture conditions) on cumulative gas fluxes was evaluated with a post hoc Tukey's Honest Significant Difference test. Temperature sensitivity $\left(Q_{10}\right)$ was calculated for each gas and treatment as $\frac{F_{2}}{F_{1}}\left(\frac{10}{T_{2}-T_{1}}\right)$, where $F_{1}$ and $F_{2}$ are the cumulative gas fluxes $\left(\mathrm{mg} \mathrm{C}^{-1}\right)$ at temperatures $T_{1}$ and $T_{2}\left({ }^{\circ} \mathrm{C}\right)$, respectively.

All data analysis and statistics were performed using $\mathrm{R}$ version 3.3.1 (21 June 2016) ( $\mathrm{R}$ Core Team, 2016). This experiment was run as an "open experiment" (Bond-Lamberty et al., 2016b) with all analysis code, data (from raw instrument data to final summaries), diagnostics, etc., available at https://github.com/bpbond/cpcrw_ incubation. The summarized flux data backing the main results have been archived under the Digital Object Identifier doi:10.6084/m9.figshare.4240436.v1.

\section{Results}

The 30 experimental cores had a bulk density of $1.00 \pm 0.18$ (mean $\pm \mathrm{sd}) \mathrm{g} \mathrm{cm}^{-3}$. Large $(>2 \mathrm{~mm})$ particles, primarily schist, comprised $41 \% \pm 11 \%$ of the cores' total mass. Soil $(\leq 2 \mathrm{~mm})$ dry mass was $886 \pm 154 \mathrm{~g}$. Sample DOC was $157.93 \pm 55.74 \mathrm{mg} \mathrm{kg}^{-1}$. Carbon content was $1.20 \% \pm 1.19 \%$, while $\mathrm{N}$ content was $0.06 \% \pm 0.06 \%$. Mean C: $\mathrm{N}$ was 20.7. Neither temperature nor moisture treatment exerted any significant effect $(P>0.1$ for all) on these highly variable properties (Table 1 ).

Gravimetric water content was $0.31 \pm 0.12$ (min 0.19, $\max 0.77$ ) at the beginning of the incubation (Fig. 1). "Field moisture" cores were on average unchanged $(0.33 \pm 0.13)$ at the end of the incubation, but both the drought treatments, which did not differ from each other in their effect

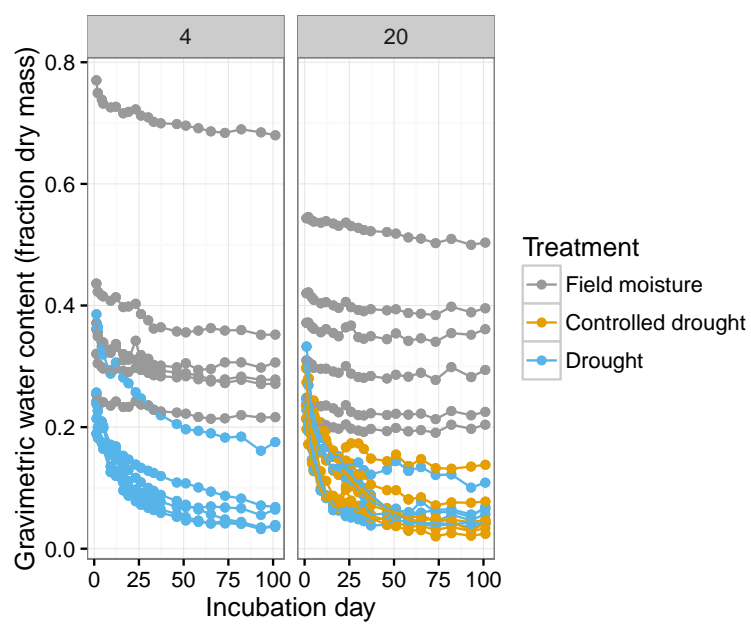

Figure 1. Core water content across the course of the incubation experiment by temperature (left panel $4^{\circ} \mathrm{C}$, right panel $20^{\circ} \mathrm{C}$ ) and treatment.

on gravimetric water content $(P=0.880)$, had declined to $0.06 \pm 0.04$. Volumetric water content values ranged from $0.29 \pm 0.05(\min 0.23, \max 0.43)$ at the beginning of the experiment to $0.15 \pm 0.11(\min 0.03, \max 0.38)$ at the end across all cores. Water-filled pore space, assuming a particle density of $2.65 \mathrm{~g} \mathrm{~cm}^{-3}$, was $22-65 \%$ over all cores, moisture treatments, and temperatures.

Carbon dioxide fluxes during the incubation ranged from $1.1 \mu \mathrm{g} \mathrm{CgC}^{-1} \mathrm{day}^{-1}$ to a maximum of $5245.1 \mu \mathrm{g} \mathrm{C} \mathrm{C}^{-1} \mathrm{day}^{-1}$, with a mean of $248.9 \mu \mathrm{g} \mathrm{Cg} \mathrm{C}^{-1}$ day $^{-1}$ over the 100 days. $\mathrm{CH}_{4}$ rates ranged from $0.00 \mathrm{ngCgC}^{-1} \mathrm{day}^{-1}$ to a maximum of $1.31 \mathrm{ng} \mathrm{g} \mathrm{C}^{-1}$ day $^{-1}$, with a mean of $0.06 \mathrm{ng} \mathrm{CgC}^{-1}$ day $^{-1}$. These means conceal considerable variability over the course of the incubation (Table 1 , Figs. 2 and 3).

In the linear mixed-effect model (AIC $=2992.6$ ), instantaneous $\mathrm{CO}_{2}$ flux was positively correlated with incubation chamber temperature, core gravimetric water content, and percent soil N (all $P<0.05$, and the latter two $P<0.001$; Table 2). Temperature sensitivity decreased significantly $(P<0.001)$ over the course of the incubation, while moisture sensitivity was unaffected by time. Percent $C$ and percent $\mathrm{N}$ were highly correlated $(r=0.99)$ for these cores. Because percent $\mathrm{N}$ was a slightly stronger predictor, it was retained in the model while percent $C$ was excluded; see Colman and Schimel (2014). The interaction between water content and percent $\mathrm{N}$ was also highly significant $(P<0.001)$, although cores with $\mathrm{N}>0.2 \%$ exhibited little relationship between water content and $\mathrm{CO}_{2}$ flux (data not shown). Instantaneous $\mathrm{CH}_{4}$ fluxes were positively correlated with percent $\mathrm{N}$, while water content exhibited significant interactions with percent $\mathrm{N}$ and DOC as a predictor (Table A1). This model had little predictive power (AIC $=-10879.2$ ), however, and neither 
Table 1. Summary of dissolved organic carbon (DOC), percent C, percent N, bulk density (BD), and $\mathrm{CO}_{2}$ and $\mathrm{CH}_{4}$ fluxes by treatment. The field moisture and drought columns summarize (mean \pm s.d.) 12 cores, combining two groups of $\mathrm{N}=6$ at each incubation temperature, while the controlled drought and pre-incubation columns are $\mathrm{N}=6$.

\begin{tabular}{lrrrr}
\hline Variable & Field moisture & Controlled drought & Drought & Preincubation \\
\hline $\mathrm{DOC}\left(\mathrm{mg} \mathrm{kg}^{-1}\right)$ & $173.62 \pm 46.67$ & $165.68 \pm 66.46$ & $154.60 \pm 57.15$ & $125.43 \pm 49.07$ \\
$\mathrm{C}(\%)$ & $1.67 \pm 1.60$ & $0.87 \pm 0.50$ & $0.76 \pm 0.60$ & $1.44 \pm 1.32$ \\
$\mathrm{~N}(\%)$ & $0.08 \pm 0.08$ & $0.04 \pm 0.03$ & $0.03 \pm 0.03$ & $0.07 \pm 0.06$ \\
$\mathrm{BD}\left(\mathrm{g} \mathrm{cm}^{-3}\right)$ & $0.89 \pm 0.18$ & $1.06 \pm 0.17$ & $1.08 \pm 0.14$ & $1.13 \pm 0.29$ \\
$\mathrm{CO}_{2}\left(\mu \mathrm{g} \mathrm{Cg} \mathrm{C}^{-1} \mathrm{day}^{-1}\right)$ & $456.40 \pm 543.91$ & $159.77 \pm 116.41$ & $97.03 \pm 96.38$ & - \\
$\mathrm{CH}_{4}\left(\mathrm{ng} \mathrm{g} \mathrm{C} \mathrm{C}^{-1} \mathrm{day}^{-1}\right)$ & $0.10 \pm 0.00$ & $0.10 \pm 0.00$ & $0.10 \pm 0.00$ & - \\
\hline
\end{tabular}

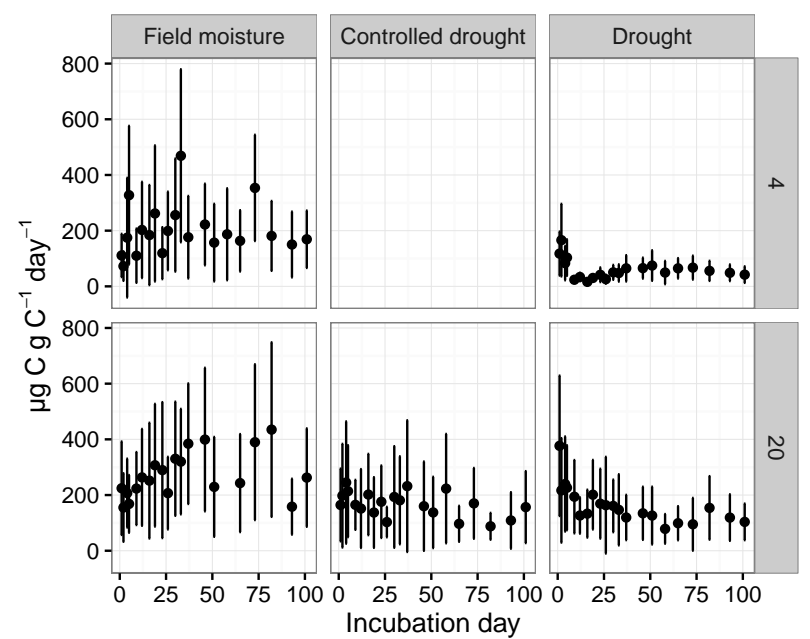

Figure 2. Mass-normalized $\mathrm{CO}_{2}$ fluxes over the 100-day incubation by temperature $\left(4\right.$ and $20^{\circ} \mathrm{C}$, rows) and treatment (field moisture, drought, and controlled drought; columns). Error bars show core-tocore standard deviation. The controlled drought treatment, for $20^{\circ} \mathrm{C}$ only, was meant to dry cores at roughly the same rate as the drought cores at $4{ }^{\circ} \mathrm{C}$.

temperature nor water content was a significant first-order predictor of $\mathrm{CH}_{4}$ fluxes.

The cumulative production of $\mathrm{C}$ from $\mathrm{CO}_{2}$ (Fig. 4) was over 6 orders of magnitude higher than that from $\mathrm{CH}_{4}$, with $\mathrm{CO}_{2}: \mathrm{CH}_{4} \mathrm{C}$ ratios ranging from 1.4 million in the $4{ }^{\circ} \mathrm{C}$ field moisture treatment to 6.2 million in the $20^{\circ} \mathrm{C}$ field moisture treatment. Cumulative evolved $\mathrm{CO}_{2}$ was highly affected by temperature $(P=0.003)$, and field moisture cores emitted significantly more $\mathrm{CO}_{2}$ than the other two moisture treatments at both temperatures $(P<0.001$ for both, with no significant interactive effect). There was no difference between fluxes from the $20^{\circ} \mathrm{C}$ drought and controlled drought treatments $(P=0.377)$. Drought cores' cumulative production was $73 \%\left(4{ }^{\circ} \mathrm{C}\right)$ and $52 \%\left(20^{\circ} \mathrm{C}\right)$ lower than the cores kept at field moisture. Neither temperature $(P=0.200)$ nor moisture treatment (mean $P=0.975$ ) was a significant factor in predicting cumulative $\mathrm{CH}_{4}$ fluxes.

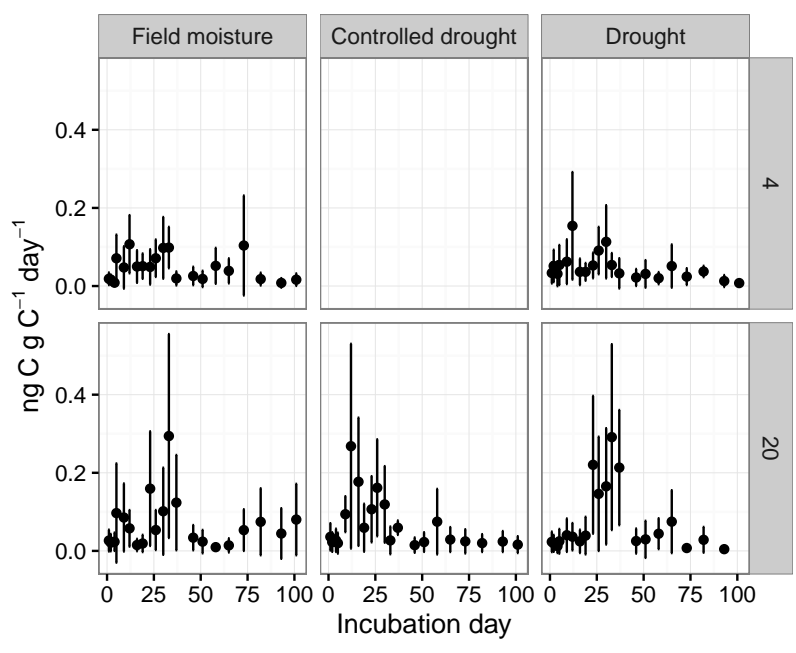

Figure 3. Mass-normalized $\mathrm{CH}_{4}$ fluxes over the 100-day incubation by temperature $\left(4\right.$ and $20^{\circ} \mathrm{C}$, rows) and treatment (field moisture, drought, and controlled drought; columns). Error bars show core-tocore standard deviation. The controlled drought treatment, for $20^{\circ} \mathrm{C}$ only, was meant to dry cores at roughly the same rate as the drought cores at $4{ }^{\circ} \mathrm{C}$.

The cumulative flux numbers above result in $\mathrm{CO}_{2}$ temperature sensitivity $\left(Q_{10}\right)$ values of 1.3 and 1.9 for the field moisture and drought treatments, respectively; the corresponding $Q_{10}$ values based on cumulative $\mathrm{CH}_{4}$ were 1.2 and 1.3. Computing $Q_{10}$ values based on fluxes normalized by water-filled pore space changed these values only slightly: to 1.2 and 1.7 for $\mathrm{CO}_{2}$, for the field moisture and drought treatments, respectively, and 1.1 and 1.2 for $\mathrm{CH}_{4}$.

\section{Discussion}

Rises in boreal air temperatures, and unpredictable precipitation changes, will change fire disturbance regimes, warm and dry many soils, increase vegetation stress, degrade permafrost, and deepen the active layer (Schuur et al., 2015), all with uncertain consequences for soil dynamics and GHG fluxes. In this laboratory experiment we found that $\mathrm{CO}_{2}$ 
Table 2. Linear mixed-effect model parameters, testing effects of temperature $\left({ }^{\circ} \mathrm{C}\right)$, gravimetric water content (unitless), soil C $(\%)$, soil $\mathrm{N}$ $(\%)$, and dissolved organic carbon ( $\left.\mathrm{mg} \mathrm{kg}^{-1}\right)$ on individual core $\mathrm{CO}_{2}$ fluxes $\left(+0.1 \mu \mathrm{g} \mathrm{C} \mathrm{C} \mathrm{C}^{-1} \mathrm{day}^{-1}\right)$; a colon (“:”) indicates an interaction. Dependent variable has units of $\log \left(\mu \mathrm{g} \mathrm{C} \mathrm{C} \mathrm{C}^{-1} \mathrm{day}^{-1}\right)$. Columns include parameter value, standard error (SE), degrees of freedom (DF), $T$ statistic, and $P$ value.

\begin{tabular}{lrrrrr}
\hline & Value & SE & DF & $T$ & $P$ \\
\hline (Intercept) & 1.713 & 0.354 & 1153 & 4.839 & $<0.001$ \\
Temperature & 0.046 & 0.020 & 26 & 2.336 & 0.027 \\
WC_gravimetric & 3.496 & 1.052 & 1153 & 3.322 & 0.001 \\
N_percent & 37.976 & 6.810 & 26 & 5.576 & $<0.001$ \\
Temperature : WC_gravimetric & 0.116 & 0.061 & 1153 & 1.905 & 0.057 \\
Temperature : N_percent & -0.507 & 0.300 & 26 & -1.690 & 0.103 \\
WC_gravimetric: N_percent & -37.347 & 8.425 & 1153 & -4.433 & $<0.001$ \\
\hline
\end{tabular}

fluxes, but not $\mathrm{CH}_{4}$ fluxes, from these oxic active-layer mineral soils were sensitive to temperature and, in particular, moisture.

A number of studies have measured microbial respiration and GHG fluxes very close to our study site. Morishita et al. (2014) quantified GHG fluxes at CPCRW and nearby forests and found $\mathrm{CO}_{2}$ production to be correlated with both temperature and moisture in upland cryosols, consistent with our results. Waldrop et al. (2010) incubated active-layer and permafrost soils from Picea mariana sites near Fairbanks, AK, observing aerobic $Q_{10}$ values of 9.0 (active layer) and 2.3 (permafrost) from -5 to $5{ }^{\circ} \mathrm{C}$, and flux rates of $0.001-0.10 \mu \mathrm{mol} \mathrm{CH}_{4}$ day $^{-1} \mathrm{~g}^{-1} \quad(\sim 0.001-$ $\left.0.133 \mathrm{ng} \mathrm{Cg} \mathrm{C}^{-1} \mathrm{day}^{-1}\right)$ and $\sim 1-5 \mu \mathrm{g} \mathrm{C}-\mathrm{CO}_{2} \mathrm{~h}^{-1} \mathrm{~g}^{-1}$ ( 2000-10000 $\mu \mathrm{g} \mathrm{Cg} \mathrm{C}^{-1} \mathrm{day}^{-1}$ ), considerably higher than the $\mathrm{CO}_{2}$ rates observed here. During the first 100 days of an incubation of Fairbanks-area $0-10 \mathrm{~cm}$ mineral soils, Neff and Hooper (2002) observed fluxes of $~ 55-409 \mu \mathrm{g} \mathrm{C}$ $\mathrm{CO}_{2} \mathrm{~g} \mathrm{C}^{-1} \mathrm{day}^{-1}$, in line with the results here, while Wickland and Neff (2008) reported that temperature and moisture exhibited interactive effects, of similar magnitude, on decomposition in P. mariana soils.

A number of synthesis studies have documented dynamics and $\mathrm{C}$ feedback potential of Arctic and boreal soils more generally; comparing to these results is useful because although the response of soil biota to stresses such as drought tends to differ between soil types, organisms, and vegetation, it is often broadly similar across biomes and climatic conditions (Manzoni et al., 2012). Using two metanalyses of aerobic and anaerobic permafrost soil incubations, Schädel et al. (2016) showed that $\mathrm{C}$ release was highly sensitive to temperature and that soils released far more $(220-520 \%) \mathrm{C}$ under aerobic conditions. Our incubation was fully aerobic, but its results are consistent with the conclusion that respiration in the form of $\mathrm{CO}_{2}$ is likely to dominate the high-latitude $\mathrm{C}$ feedback, and that aerobic soils, and the conditions under which currently waterlogged soils may drain, deserve particular attention. In terms of absolute flux rates, Treat et al. (2015) reported mean $\mathrm{CO}_{2}$ rates of 47 (all mineral soils) and 101 (for $20-100 \mathrm{~cm}$ soils) $\mu \mathrm{g} \mathrm{C}-\mathrm{CO}_{2} \mathrm{~g} \mathrm{C}^{-1}$ day $^{-1}$ from a pan-Arctic synthesis of anaerobic soil incubations, which is somewhat lower than our aerobic incubation results. Treat et al. (2014) also found $\mathrm{CO}_{2}$ and $\mathrm{CH}_{4}$ emissions to be strongly correlated with temperature and moisture based on an incubation of Alaskan peats. Whether climate change makes northern regions wetter or drier is thus a critical factor affecting the quantity and form of $\mathrm{C}$ release.

The drought treatment imposed in this experiment reduced soil C fluxes by $52-73 \%$. The importance of this result depends, in part, on the spatial extent and intensity of precipitation changes across the boreal and Arctic during this century. There is a detectable anthropogenic influence in high-latitude precipitation changes (Wan et al., 2015), but these changes are inconsistent: drier and warmer conditions in boreal Eurasia (Buermann et al., 2014), for example, but growing season length increases in interior Alaska with no increase in precipitation (Wendler and Shulski, 2009). This spatial variability will interact with permafrost thaw dynamics to produce a complex patchwork of soil moisture changes (Zhang et al., 2012; Watts et al., 2012). The high uncertainty in this area makes it all the more important to understand the interactive effects of soil moisture and temperature on decomposition and GHG emissions (Sierra et al., 2015).

We observed very low but positive $\mathrm{CH}_{4}$ production from these upland mineral soils. This is in contrast to many field studies that have observed $\mathrm{CH}_{4}$ uptake (oxidation) in dry boreal sites (Matson et al., 2009; Schaufler et al., 2010). Anoxic microsites in soil can however provide enough $\mathrm{CH}_{4}$ production to balance low-level consumption in otherwise aerobic soils (Kammann et al., 2009). In addition, our results are broadly consistent with data from 65 studies summarized by Olefeldt et al. (2013), who found that $\mathrm{CH}_{4}$ emissions were more sensitive to soil temperature in wetter ecosystems; it would have been a surprise if the little methanogenic activity in our upland, well-drained soils was temperature-sensitive at all. Methane was also a far smaller $\mathrm{C}$ flux than $\mathrm{CO}_{2}$ from these soils, in particular at higher temperatures $\left(\mathrm{as} \mathrm{CO}_{2}\right.$ was responsive to temperature, but $\mathrm{CH}_{4}$ was not). This is true more generally: for example, Treat et al. (2015) found a median $\mathrm{CO}_{2}: \mathrm{CH}_{4}$ production ratio of 387 for anaerobic incu- 


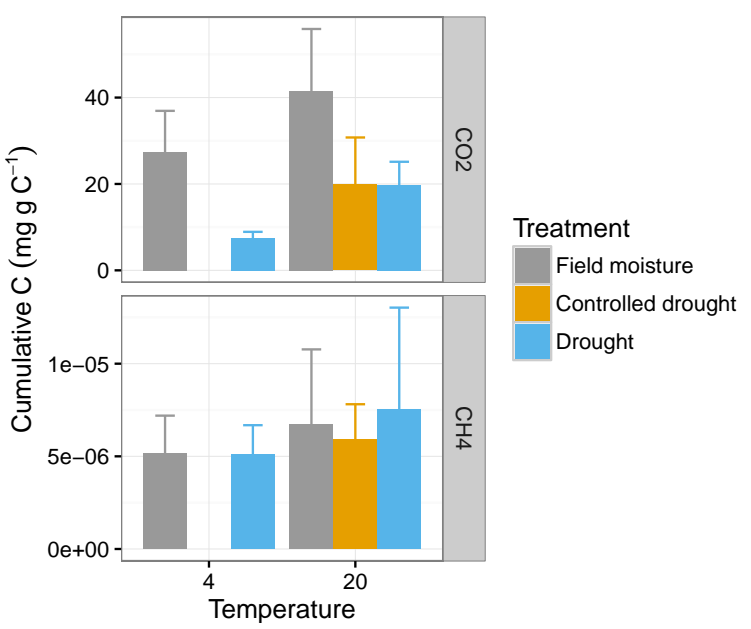

Figure 4. Cumulative mass-normalized $\mathrm{C}$ fluxes $\left(\mathrm{mg} \mathrm{g} \mathrm{C}^{-1}\right)$ over the incubation by gas $\left(\mathrm{CO}_{2}\right.$ and $\mathrm{CH}_{4}$, top and bottom panels, respectively), treatment (columns), and temperature ( $x$ axis, ${ }^{\circ} \mathrm{C}$ ). Letters within a panel indicate significant differences based on Tukey's HSD.

bations of boreal soils. This is naturally far lower than our observed aerobic (and thus high- $\mathrm{CO}_{2}$ ) ratios, but nonetheless consistent with them. Thus, we see little opportunity for $\mathrm{CH}_{4}$ to be a significant contributor to the upland soil $\mathrm{C}$ fluxes and climate feedback risk, even accounting for the 25 times stronger radiative forcing of this gas over a 100-year time horizon (Lee et al., 2012).

\subsection{Temperature vs. moisture sensitivity for cumulative emissions}

The cumulative GHG fluxes (Fig. 4) integrate the entire 100day incubation, eliminating the day-to-day variability of instantaneous fluxes and are thus more generalizable. Our results suggest that moisture limitation could exert a large effect on $\mathrm{CO}_{2}$ production for deep active-layer soils: drought cores' cumulative production was $73 \%\left(4{ }^{\circ} \mathrm{C}\right)$ and $52 \%$ $\left(20^{\circ} \mathrm{C}\right)$ lower than the cores kept at field moisture. This effect was highly significant, and suggests that moisture limitations could exert a significant constraint on deep active-layer soils as they slowly warm. Such moisture constraints are thought to be already exerting effects on vegetation and soil fluxes at large scales (Ju and Masek, 2016; Bond-Lamberty et al., 2012), but our understanding of the interactive effects involved is poor.

The $Q_{10}$ values observed in this experiment were low (all less than 2.0, even when controlling for changes in soil moisture). Temperature sensitivities of $\sim 2$ are more typical (Dutta et al., 2006; Schädel et al., 2016), although the temperature sensitivity of $\mathrm{C}$ release can change over time of incubation (Dutta et al., 2006) and vary between soil fractions cycling over different time horizons (Karhu et al., 2010; Schädel et al., 2014). Observed surface $\mathrm{CO}_{2}$ fluxes at this
CPCRW site exhibited a $Q_{10}$ of $5.1 \pm 1.4$ over a temperature range of $3.5-15^{\circ} \mathrm{C}$ (C. Anderson, personal communication, 2016); however, these surface fluxes were measured over multiple months and include root respiration preventing any direct comparison. While increased temperature does not always drive $\mathrm{C}$ mineralization rates in forest mineral soils (Giardina and Ryan, 2000), it is linked with increases in soil moisture content and can lead to changes in microbial community structure and GHG fluxes (Xue et al., 2016).

Interestingly, $Q_{10}$ values were lower in the drought treatment cores, a mathematical consequence of the fact that drought restricted $\mathrm{CO}_{2}$ respiration more at 4 than at $20^{\circ} \mathrm{C}$. There is evidence that climate warming changes the microbial decay dynamics of soil organic $\mathrm{C}$ compounds generally considered to be stable (Frey et al., 2013; BondLamberty et al., 2016a). Conditions such as drought can change the amount and quality of DOC available to microbes (1999), but we observed no DOC changes between treatments here. Deep active-layer soils store large quantities of soil C (Mueller et al., 2015) but are not subject to abundant inputs of fresh $\mathrm{C}$ from vegetation. Therefore, the starting quality of the native soil $\mathrm{C}$ in active-layer soils is older, more microbially processed, and dominated by more stable "heavy" organic C (Karlsson et al., 2011). Thus, it may not be surprising that these more stable $\mathrm{C}$ compounds would be metabolized by processes that have been reported to be less temperature-sensitive.

\subsection{Soil nitrogen}

Somewhat unexpectedly, percent soil $\mathrm{N}$ was very significantly and positively correlated with both $\mathrm{CO}_{2}$ and $\mathrm{CH}_{4}$ fluxes (Tables 2 and 3). Nitrogen interacts with microbial respiration via a number of complex, interactive, and still unclear mechanisms (Luo and Zhou, 2006), including reductions in belowground plant allocation, shifts in energy source or population of the saprotrophic community (Saiya-Cork et al., 2002) that leave it less capable of decomposing recalcitrant compounds, and perhaps abiotic stabilization mechanisms (Janssens et al., 2010). Metanalyses have generally shown negative to neutral effects of $\mathrm{N}$ deposition on microbial biomass (Treseder, 2008) and respiration (Ramirez et al., 2012) and total soil respiration across ecosystems and biomes (Janssens et al., 2010; Zhou et al., 2014). These effect are likely due to several mechanisms involving soil $\mathrm{pH}$, ligninase enzymes, and phenol oxidase activity (Luo and Zhou, 2006), and incubation results examining $\mathrm{N}$ effects can be highly variable (Lavoie et al., 2011; Sistla et al., 2012). Some studies have however observed positive correlations between ambient soil $\mathrm{N}$ and microbial respiration. For example, Weiss et al. (2015) found $\mathrm{CO}_{2}$ production from Siberian Yedoma permafrost samples to be correlated with both percent $\mathrm{C}$ and $\mathrm{N}$, consistent with our active-layer results (Table 2).

The $\mathrm{C}: \mathrm{N}$ ratio was not a significant predictor of $\mathrm{GHG}$ fluxes in this study, although this ratio has been found to be 
important in metanalyses (Sistla et al., 2012; Schädel et al., 2014). In situ respiration rates have also been shown to be negatively correlated with $\mathrm{C}: \mathrm{N}$ at large spatial scales (Allaire et al., 2012). Percent $\mathrm{C}$ and $\mathrm{N}$ both varied widely in our soil cores (Table 1) and were highly correlated with each other, even though the cores were collected within tens of meters of each other. This suggests that active-layer SOC response to temperature and moisture may also be highly spatially variable, even in a mixed-species boreal forest that we expected, a priori, to provide spatial variation in litter and SOC quality (Fierer et al., 2005). Spatially explicit analyses of soil biochemistry, temperatures (Bond-Lamberty et al., 2005), and respiration (Allaire et al., 2012) are likely necessary to accurately constrain and predict soil fluxes in this ecosystem.

\subsection{Limitations and weaknesses}

There were weaknesses in our approach and experimental design that should be considered. Laboratory experiments offer precise control but lack the in situ nature of field manipulations (Sistla et al., 2013), raising uncertainties as to what degree their results can be extrapolated. Soils isolated during incubation may, for example, underestimate temperature sensitivity of respiration (Podrebarac et al., 2016) or exhibit lag effects (Treat et al., 2015). It should also be noted that our 100-day incubation was not long enough to observe slowly cycling soil fractions, which may vary in their response to experimental manipulation (Karhu et al., 2010). Nonetheless, the controlled environments of incubations provide an important way to elucidate the key mechanisms controlling GHG from high-latitude soils (Schuur et al., 2015).

The soils studied here were from an upland, mixed conifer-deciduous boreal forest, and care needs to be taken before drawing regional inferences or inferences about other ecosystem types. We focused on an experimental drought rather than flooding because of the well-drained nature of the field site: it is unlikely that the mid-slope forest we sampled in will ever suffer from thermokarst or excessive soil moisture, but too-dry conditions are a serious possibility in this relatively low-precipitation ecosystem (Barber et al., 2000).
Finally, the soils here are not surface-layer soils (where the majority of microbial activity and $\mathrm{C}$ mineralization of labile $\mathrm{C}$ takes place); removing them from in situ conditions (where they are less exposed to $\mathrm{O}_{2}$, for example) may significantly change the abiotic conditions to which the microbial community is adapted. However, focusing on the active layer provides crucial information about the potential loss of $\mathrm{C}$ from these soils, a risk that needs to be well understood since permafrost degradation leads to expansions in the depth of the active layer across the Arctic.

\section{Conclusions}

In this laboratory experiment, we found that $\mathrm{CO}_{2}$ fluxes were strongly influenced by temperature and water content and correlated with soil $\mathrm{C}$ and $\mathrm{N}$, while $\mathrm{CH}_{4}$ fluxes were much smaller and not sensitive to temperature or water content in these well-drained mineral soils. These results add to a growing body of Arctic permafrost and active-layer incubation literature, and they underscore the importance of understanding moisture effects on $\mathrm{CO}_{2}$ fluxes in particular. How soil moisture might change with spatially variable permafrost degradation, how soil biota will respond to these changes, and how models should treat soil organic matter decomposition with respect to multiple and interacting drivers are all critical areas of research going forward. Further controlled field and laboratory studies, ideally tightly integrated with modeling experiments, are important for understanding GHG emission dynamics of high-latitude soils.

\section{Data availability}

See Sect. 2.3 for further information. 


\section{Appendix A}

Table A1. Linear mixed-effect model parameters, testing effects of temperature $\left({ }^{\circ} \mathrm{C}\right)$, gravimetric water content (unitless), soil $\mathrm{N}(\%)$, and dissolved organic carbon (DOC, $\mathrm{mg} \mathrm{kg}^{-1}$ ) on log-transformed, individual core $\mathrm{CH}_{4}$ fluxes $\left(+0.1 \mu \mathrm{g} \mathrm{C}^{-1}\right.$ day $\left.^{-1}\right)$; a colon (“":”) indicates an interaction. Dependent variable has units of $\log \left(\mu \mathrm{g} \mathrm{g} \mathrm{C}^{-1} \mathrm{day}^{-1}\right)$. Columns include parameter value, standard error (SE), degrees of freedom (DF), $T$ statistic, and $P$ value.

\begin{tabular}{lrrrrr}
\hline & Value & SE & DF & $T$ & $P$ \\
\hline (Intercept) & 1.713 & 0.354 & 1153 & 4.839 & $<0.001$ \\
Temperature & 0.046 & 0.020 & 26 & 2.336 & 0.027 \\
WC_gravimetric & 3.496 & 1.052 & 1153 & 3.322 & 0.001 \\
N_percent & 37.976 & 6.810 & 26 & 5.576 & $<0.001$ \\
Temperature : WC_gravimetric & 0.116 & 0.061 & 1153 & 1.905 & 0.057 \\
Temperature : N_percent & -0.507 & 0.300 & 26 & -1.690 & 0.103 \\
WC_gravimetric:N_percent & -37.347 & 8.425 & 1153 & -4.433 & $<0.001$ \\
\hline
\end{tabular}


Author contributions. Ben Bond-Lamberty, A. Peyton Smith, and Vanessa Bailey designed this experiment. Ben Bond-Lamberty and A. Peyton Smith performed field sampling, and A. Peyton Smith led the laboratory incubation and analyses. Ben Bond-Lamberty wrote the paper, with contributions from all authors.

Acknowledgements. We are grateful to Jamie Hollingsworth for information about, and facilitating access to, the Caribou Poker Creeks Research Watershed Long-Term Ecological Research site. This research was supported by the US Department of Energy, Office of Science, Biological and Environmental Research as part of the Terrestrial Ecosystem Sciences Program. The Pacific Northwest National Laboratory is operated for DOE by Battelle Memorial Institute under contract DE-AC05-76RL01830.

Edited by: M. Weintraub

Reviewed by: three anonymous referees

\section{References}

Alexander, H. D. and Mack, M. C.: A canopy shift in interior Alaskan boreal forests: consequences for above- and belowground carbon and nitrogen pools during post-fire succession, Ecosystems, 19, 98-114, doi:10.1007/s10021-015-9920-7, 2016.

Allaire, S. E., Lange, S. F., Lafond, J. A., Pelletier, B., Cambouris, A. N., and Dutilleul, P.: Multiscale spatial variability of $\mathrm{CO}_{2}$ emissions and correlations with physico-chemical soil properties, Geoderma, 170, 251-260, doi:10.1016/j.geoderma.2011.11.019, 2012.

Bailey, V. L., Bilskis, C. L., Fansler, S. J., McCue, L. A., Smith, J. L., and Konopka, A.: Measurements of microbial community activities in individual soil macroaggregates, Soil Biol. Biochem., 48, 192-195, doi:10.1016/j.soilbio.2012.01.004, 2012.

Barber, V. A., Juday, G. P., and Finney, B. P.: Reduced growth of Alaskan white spruce in the twentieth century from temperatureinduced drought stress, Nature, 405, 668-673, 2000.

Bieniek, P. A., Walsh, J. E., Thoman, R. L., and Bhatt, U. S.: Using climate divisions to analyze variations and trends in Alaska temperature and precipitation, J. Climate, 27, 2800-2818, doi:10.1175/JCLI-D-13-00342.1, 2014.

Bond-Lamberty, B., Wang, C., and Gower, S. T.: Spatiotemporal measurement and modeling of boreal forest soil temperatures, Agr. Forest Meteorol., 131, 27-40, doi:10.1016/j.agrformet.2005.04.008, 2005.

Bond-Lamberty, B., Bunn, A. G., and Thomson, A. M.: Multi-year lags between forest browning and soil respiration at high northern latitudes, PLoS ONE, 7, e50441, doi:10.1371/journal.pone.0050441, 2012.

Bond-Lamberty, B., Bolton, H. J., Fansler, S. J., Heredia-Langner, A., Liu, C., McCue, L. A., Smith, J. L., and Bailey, V. L.: Soil respiration and bacterial structure and function after 17 years of a reciprocal soil transplant experiment, PLoS ONE, 11, e0150599, doi:10.1371/journal.pone.0150599, 2016a.

Bond-Lamberty, B., Smith, A. P., and Bailey, V. L.: Running an open experiment: transparency and reproducibility in soil and ecosystem science, Environ. Res. Lett., 11, 084004, doi:10.1088/1748-9326/11/8/084004, 2016b.
Buermann, W., Parida, B., Jung, M., MacDonald, G. M., Tucker, C. J., and Reichstein, M.: Recent shift in Eurasian boreal forest greening response may be associated with warmer and drier summers, Geophys. Res. Lett., 41, 1995-2002, doi:10.1002/2014GL059450, 2014.

Colman, B. P. and Schimel, J. P.: Drivers of microbial respiration and net $\mathrm{N}$ mineralization at the continental scale, Soil Biol. Biochem., 60, 65-76, doi:10.1016/j.soilbio.2013.01.003, 2014.

Davidson, E. A. and Janssens, I. A.: Temperature sensitivity of soil carbon decomposition and feedbacks to climate change, Nature, 440, 165-173, doi:10.1038/nature04514, 2006.

Davies, L. and Gather, U.: The identification of multiple outliers, J. Am. Stat. Assoc., 88, 782-792, 1993.

Dutta, K., Schuur, E. A. G., Neff, J. C., and Zimov, S. A.: Potential carbon release from permafrost soils of Northeastern Siberia, Glob. Change Biol., 12, 2336-2351, doi:10.1111/j.13652486.2006.01259.x, 2006.

Elberling, B., Michelsen, A., Schädel, C., Schuur, E. A. G., Christiansen, H. H., Berg, L., Tamstorf, M. P., and Sigsgaard, C.: Long-term $\mathrm{CO}_{2}$ production following permafrost thaw, Nat. Clim. Change, 3, 890-894, doi:10.1038/nclimate1955, 2013.

Fierer, N., Craine, J. M., McLauchlan, K., and Schimel, J. P.: Litter quality and the temperature sensitivity of decomposition, Ecology, 86, 320-326, doi:10.1890/04-1254, 2005.

Frey, S. D., Lee, J., Melillo, J. M., and Six, J.: The temperature response of soil microbial efficiency and its feedback to climate, Nat. Clim. Change, 3, 395-398, doi:10.1038/nclimate1796, 2013.

Gardner, W. H.: Water content, in: Methods of Soil Analysis. Part 1. Physical and Mineralogical Methods, edited by: Klute, A., American Society of Agronomy-Soil Science Society of America, Madison, WI, 493-544, 1986.

Genet, H., McGuire, A. D., Barrett, K., Breen, A. L., Euskirchen, E. S., Johnstone, J. F., Kasischke, E. S., Melvin, A. M., Bennett, A. C., and Mack, M. C.: Modeling the effects of fire severity and climate warming on active layer thickness and soil carbon storage of black spruce forests across the landscape in interior Alaska, Environ. Res. Lett., 8, 045016, doi:10.1088/17489326/8/4/045016, 2013.

Giardina, C. P. and Ryan, M. G.: Evidence that decomposition rates of organic carbon in mineral soil do not vary with temperature, Nature, 404, 858-861, doi:10.1038/35009076, 2000.

Goulden, M. L., Wofsy, S. C., Harden, J. W., Trumbore, S. E., Crill, P. M., Gower, S. T., Fries, T., Daube, B. C., Fan, S.-M., Sutton, D. J., Bazzaz, A. M., and Munger, J. W.: Sensitivity of boreal forest carbon balance to soil thaw, Science, 279, 214-217, doi:10.1126/science.279.5348.214, 1998.

Harden, J. W., Koven, C. D., Ping, C.-L., Hugelius, G., McGuire, A. D., Camill, P., Jorgenson, T., Kuhry, P., Michaelson, G. J., O'Donnell, J. A., Schuur, E. A. G., Tarnocai, C., Johnson, K. D., and Grosse, G.: Field information links permafrost carbon to physical vulnerabilities of thawing, Geophys. Res. Lett., 39, L15704, doi:10.1029/2012GL051958, 2012.

Hartley, I. P., Garnett, M. H., Sommerkorn, M., Hopkins, D. W., Fletcher, B. J., Sloan, V. L., Phoenix, G. K., and Wookey, P. A.: A potential loss of carbon associated with greater plant growth in the European Arctic, Nat. Clim. Change, 2, 875-879, doi:10.1038/nclimate1575, 2012. 
Hashimoto, S., Carvalhais, N., Ito, A., Migliavacca, M., Nishina, K., and Reichstein, M.: Global spatiotemporal distribution of soil respiration modeled using a global database, Biogeosciences, 12, 4121-4132, doi:10.5194/bg-12-4121-2015, 2015.

Helbig, M., Pappas, C., and Sonnentag, O.: Permafrost thaw and wildfire: Equally important drivers of boreal tree cover changes in the Taiga Plains, Canada, Geophys. Res. Lett., 43, 1598-1606, doi:10.1002/2015GL067193, 2016.

Hinzman, L. D., Bettez, N. D., Bolton, W. R., Chapin, F. S., Dyurgerov, M. B., Fastie, C. L., Griffith, B., Hollister, R. D., Hope, A., Huntington, H. P., Jensen, A. M., Jia, G. J., Jorgenson, T., Kane, D. L., Klein, D. R., Kofinas, G., Lynch, A. H., Lloyd, A. H., McGuire, A. D., Nelson, F. E., Oechel, W. C., Osterkamp, T. E., Racine, C. H., Romanovsky, V. E., Stone, R. S., Stow, D. A., Sturm, M., Tweedie, C. E., Vourlitis, G. L., Walker, M. D., Walker, D. A., Webber, P. J., Welker, J. M., Winker, K. S., and Yoshikawa, K.: Evidence and implications of recent climate change in northern Alaska and other Arctic regions, Climatic Change, 72, 251-298, doi:10.1007/s10584-005-5352-2, 2005.

Högberg, M. N., Högberg, P., and Myrold, D. D.: Is microbial community composition in boreal forest soils determined by $\mathrm{pH}$, C-to-N ratio, the trees, or all three?, Oecologia, 150, 590-601, doi:10.1007/s00442-006-0562-5, 2007.

Hugelius, G., Strauss, J., Zubrzycki, S., Harden, J. W., Schuur, E. A. G., Ping, C.-L., Schirrmeister, L., Grosse, G., Michaelson, G. J., Koven, C. D., O’Donnell, J. A., Elberling, B., Mishra, U., Camill, P., Yu, Z., Palmtag, J., and Kuhry, P.: Estimated stocks of circumpolar permafrost carbon with quantified uncertainty ranges and identified data gaps, Biogeosciences, 11, 6573-6593, doi:10.5194/bg-11-6573-2014, 2014.

IPCC: Working Group I contribution to the IPCC Fifth Assessment Report Climate Change 2013: The Physical Science Basis, 1552, Geneva, Switzerland, 2013.

Janssens, I. A., Dieleman, W. I. J., Luyssaert, S., Subke, J.A., Reichstein, M., Ceulemans, R., Ciais, P., Dolman, A. J., Grace, J., Matteucci, G., Papale, D., Piao, S., Schulze, E.-D., Tang, J., and Law, B. E.: Reduction of forest soil respiration in response to nitrogen deposition, Nat. Geosci., 3, 315-322, doi:10.1038/ngeo844, 2010.

Johnstone, J. F., Hollingsworth, T. N., Chapin, F. S., and Mack, M. C.: Changes in fire regime break the legacy lock on successional trajectories in Alaskan boreal forest, Glob. Change Biol., 16, 1281-1295, doi:10.1111/j.1365-2486.2009.02051.x, 2010.

Jorgenson, M. T., Romanovsky, V. E., Harden, J. W., Shur, Y., O’Donnell, J. A., Schuur, E. A. G., Kanevskiy, M., and Marchenko, S.: Resilience and vulnerability of permafrost to climate change, Can. J. Forest Res., 40, 1219-1236, doi:10.1139/X10-060, 2010.

Ju, J. and Masek, J. G.: The vegetation greenness trend in Canada and US Alaska from 1984-2012 Landsat data, Remote Sens. Environ., 176, 1-16, doi:10.1016/j.rse.2016.01.001, 2016.

Kammann, C., Hepp, S., Lenhart, K., and Müller, C.: Stimulation of methane consumption by endogenous $\mathrm{CH}_{4}$ production in aerobic grassland soil, Soil Biol. Biochem., 41, 622-629, doi:10.1016/j.soilbio.2008.12.025, 2009.

Karhu, K., Fritze, H., Hämäläinen, K., Vanhala, P., Jungner, H., Oinonen, M., Sonninen, E., Tuomi, M., Spetz, P., Kitunen, V., and Liski, J.: Temperature sensitivity of soil carbon fractions in boreal forest soil, Ecology, 91, 370-376, doi:10.1890/09-0478.1, 2010.

Karhu, K., Auffret, M. D., Dungait, J. A. J., Hopkins, D. W., Prosser, J. I., Singh, B. K., Subke, J.-A., Wookey, P. A., Ågren, G. I., Sebastià, M.-T., Gouriveau, F., Bergkvist, G., Meir, P., Nottingham, A. T., Salinas, N., and Hartley, I. P.: Temperature sensitivity of soil respiration rates enhanced by microbial community response, Nature, 513, 81-84, doi:10.1038/nature13604, 2014.

Karlsson, E. S., Charkin, A., Dudarev, O., Semiletov, I., Vonk, J. E., Sánchez-García, L., Andersson, A., and Gustafsson, Ö.: Carbon isotopes and lipid biomarker investigation of sources, transport and degradation of terrestrial organic matter in the Buor-Khaya Bay, SE Laptev Sea, Biogeosciences, 8, 1865-1879, doi:10.5194/bg-8-1865-2011, 2011.

Kasischke, E. S., Verbyla, D. L., Rupp, T. S., McGuire, A. D., Murphy, K. A., Jandt, R., Barnes, J. L., Hoy, E. E., Duffy, P., Calef, M., and Turetsky, M. R.: Alaska's changing fire regime - implications for the vulnerability of its boreal forests, Can. J. For. Res., 40, 1313-1324, doi:10.1139/X10-098, 2010.

Kim, D.-G., Vargas, R., Bond-Lamberty, B., and Turetsky, M. R.: Effects of soil rewetting and thawing on soil gas fluxes: a review of current literature and suggestions for future research, Biogeosciences, 9, 2459-2483, doi:10.5194/bg-9-2459-2012, 2012.

Koven, C. D., Ringeval, B., Friedlingstein, P., Ciais, P., Cadule, P., Khvorostyanov, D., Krinner, G., and Tarnocai, C.: Permafrost carbon-climate feedbacks accelerate global warming, P. Natl. Acad. Sci. USA, 108, 14769-14774, doi:10.1073/pnas.1103910108, 2011.

Koven, C. D., Lawrence, D. M., and Riley, W. J.: Permafrost carbon-climate feedback is sensitive to deep soil carbon decomposability but not deep soil nitrogen dynamics, P. Natl. Acad. Sci. USA, 112, 3752-3757, doi:10.1073/pnas.1415123112, 2015.

Lavoie, M., Mack, M. C., and Schuur, E. A. G.: Effects of elevated nitrogen and temperature on carbon and nitrogen dynamics in Alaskan arctic and boreal soils, J. Geophys. Res.-Biogeo., 116, G03013, doi:10.1029/2010JG001629, 2011.

Lee, H., Schuur, E. A. G., Inglett, K. S., Lavoie, M., and Chanton, J.: The rate of permafrost carbon release under aerobic and anaerobic conditions and its potential effects on climate, Glob. Change Biol., 18, 515-527, doi:10.1111/j.13652486.2011.02519.x, 2012.

Luo, Y. and Zhou, X.: Soil Respiration and the Environment, Elsevier/Academic Press, Amsterdam, 316 pp., 2006.

Manzoni, S., Schimel, J. P., and Porporato, A.: Responses of soil microbial communities to water stress: results from a meta-analysis, Ecology, 93, 930-938, doi:10.1890/11-0026.1, 2012.

Matson, A., Pennock, D., and Bedard-Haughn, A.: Methane and nitrous oxide emissions from mature forest stands in the boreal forest, Saskatchewan, Canada, Forest Ecol. Manage., 258, 10731083, doi:10.1016/j.foreco.2009.05.034, 2009.

Morishita, T., Noguchi, K., Kim, Y., and Matsuura, Y.: $\mathrm{CO}_{2}$, $\mathrm{CH}_{4}$ and $\mathrm{N}_{2} \mathrm{O}$ fluxes of upland black spruce (Picea mariana) forest soils after forest fires of different intensity in interior Alaska, Soil Sci. Plant Nutr., 61, 98-105, doi:10.1080/00380768.2014.963666, 2014.

Mueller, C. W., Rethemeyer, J., Kao-Kniffin, J., Löppmann, S., Hinkel, K. M., and Bockheim, J. G.: Large amounts of labile organic carbon in permafrost soils of northern Alaska, Glob. Change Biol., 21, 2804-2817, doi:10.1111/gcb.12876, 2015. 
Neff, J. C. and Hooper, D. U.: Vegetation and climate controls on potential $\mathrm{CO}_{2}$, DOC and DON production in northern latitude soils, Glob. Change Biol., 8, 872-884, doi:10.1046/j.13652486.2002.00517.x, 2002.

Nicolsky, D. J., Romanovsky, V. E., Alexeev, V. A., and Lawrence, D. M.: Improved modeling of permafrost dynamics in a GCM land-surface scheme, Geophys. Res. Lett., 34, L08501, doi:10.1029/2007GL029525, 2007.

Olefeldt, D., Turetsky, M. R., Crill, P. M., and McGuire, A. D.: Environmental and physical controls on northern terrestrial methane emissions across permafrost zones, Glob. Change Biol., 19, 589-603, doi:10.1111/gcb.12071, 2013.

Pastick, N. J., Jorgenson, M. T., Wylie, B. K., Nield, S. J., Johnson, K. D., and Finley, A. O.: Distribution of near-surface permafrost in Alaska: Estimates of present and future conditions, Remote Sens. Environ., 168, 301-315, doi:10.1016/j.rse.2015.07.019, 2015.

Petrone, K. C., Jones, J. B., Hinzman, L. D., and Boone, R. D.: Seasonal export of carbon, nitrogen, and major solutes from Alaskan catchments with discontinuous permafrost, J. Geophys. Res.-Biogeo., 111, G02020, doi:10.1029/2005JG000055, 2006.

Podrebarac, F. A., Laganière, J., Billings, S. A., Edwards, K. A., and Ziegler, S. E.: Soils isolated during incubation underestimate temperature sensitivity of respiration and its response to climate history, Soil Biol. Biochem., 93, 60-68, doi:10.1016/j.soilbio.2015.10.012, 2016.

Raich, J. W. and Tufekcioglu, A.: Vegetation and soil respiration: correlations and controls, Biogeochemistry, 48, 71-90, 2000.

Ramirez, K. S., Craine, J. M., and Fierer, N.: Consistent effects of nitrogen amendments on soil microbial communities and processes across biomes, Glob. Change Biol., 18, 1918-1927, doi:10.1111/j.1365-2486.2012.02639.x, 2012.

R Core Team: R: A language and environment for statistical computing. R Foundation for Statistical Computing, Vienna, Austria, available at: https://www.R-project.org/ (last access: 20 December 2016), 2016.

Saiya-Cork, K. R., Sinsabaugh, R. L., and Zak, D. R.: The effects of long term nitrogen deposition on extracellular enzyme activity in an Acer saccharum forest soil, Soil Biol. Biochem., 34, 13091315, doi:10.1016/S0038-0717(02)00074-3, 2002.

Schädel, C., Schuur, E. A. G., Bracho, R., Elberling, B., Knoblauch, C., Lee, H., Luo, Y., Shaver, G. R., and Turetsky, M. R.: Circumpolar assessment of permafrost $\mathrm{C}$ quality and its vulnerability over time using long-term incubation data, Glob. Change Biol., 20, 641-652, doi:10.1111/gcb.12417, 2014.

Schädel, C., Bader, M. K.-F., Schuur, E. A. G., Biasi, C., Bracho, R., Čapek, P., De Baets, S., Diáková, K., Ernakovich, J., Estop-Aragonés, C., Graham, D. E., Hartley, I. P., Iversen, C. M., Kane, E. S., Knoblauch, C., Lupascu, M., Martikainen, P. J., Natali, S. M., Norby, R. J., O’Donnell, J. A., Chowdhury, T. R., Šantrůčková, H., Shaver, G. R., Sloan, V. L., Treat, C. C., Turetsky, M. R., Waldrop, M. P., and Wickland, K. P.: Potential carbon emissions dominated by carbon dioxide from thawed permafrost soils, Nat. Clim. Change, 6, 950-953, doi:10.1038/nclimate3054, 2016.

Schaefer, K., Lantuit, H., Romanovsky, V. E., Schuur, E. A. G., and Witt, R.: The impact of the permafrost carbon feedback on global climate, Environ. Res. Lett., 9, 085003, doi:10.1088/17489326/9/8/085003, 2014.
Schaufler, G., Kitzler, B., Schindlbacher, A., Skiba, U., Sutton, M. A., and Zechmeister-Boltenstern, S.: Greenhouse gas emissions from European soils under different land use: effects of soil moisture and temperature, Eur. J. Soil Sci., 61, 683-696, doi:10.1111/j.1365-2389.2010.01277.x, 2010.

Schmidt, M. W. I., Torn, M. S., Abiven, S., Dittmar, T., Guggenberger, G., Janssens, I. A., Kleber, M., Kögel-Knabner, I., Lehmann, J., Manning, D. A. C., Nannipieri, P., Rasse, D. P., Weiner, S., and Trumbore, S. E.: Persistence of soil organic matter as an ecosystem property, Nature, 478, 49-56, doi:10.1038/nature10386, 2011.

Schuur, E. A. G., Bockheim, J. G., Canadell, J. G., Euskirchen, E. S., Field, C. B., Goryachkin, S. V., Hagemann, S., Kuhry, P., Lafleur, P. M., Lee, H., Mazhitova, G., Nelson, F. E., Rinke, A., Romanovsky, V. E., Shiklomanov, N., Tarnocai, C., Venevsky, S., Vogel, J. G., and Zimov, S. A.: Vulnerability of permafrost carbon to climate change: implications for the global carbon cycle, BioScience, 58, 701-714, doi:10.1641/B580807, 2008.

Schuur, E. A. G., McGuire, A. D., Schädel, C., Grosse, G., Harden, J. W., Hayes, D. J., Hugelius, G., Koven, C. D., Kuhry, P., Lawrence, D. M., Natali, S. M., Olefeldt, D., Romanovsky, V. E., Schaefer, K., Turetsky, M. R., Treat, C. C., and Vonk, J. E.: Climate change and the permafrost carbon feedback, Nature, 520, 171-179, doi:10.1038/nature14338, 2015.

Sierra, C. A., Trumbore, S. E., Davidson, E. A., Vicca, S., and Janssens, I. A.: Sensitivity of decomposition rates of soil organic matter with respect to simultaneous changes in temperature and moisture, J. Adv. Model. Earth Syst., 7, 335-356, doi:10.1002/2014MS000358, 2015.

Sistla, S. A., Asao, S., and Schimel, J. P.: Detecting microbial N-limitation in tussock tundra soil: Implications for Arctic soil organic carbon cycling, Soil Biol. Biochem., 55, 78-84, doi:10.1016/j.soilbio.2012.06.010, 2012.

Sistla, S. A., Moore, J. C., Simpson, R. T., Gough, L., Shaver, G. R., and Schimel, J. P.: Long-term warming restructures Arctic tundra without changing net soil carbon storage, Nature, 497, 615-618, doi:10.1038/nature12129, 2013.

Treat, C. C., Wollheim, W. M., Varner, R. K., Grandy, A. S., Talbot, J., and Frolking, S. E.: Temperature and peat type control $\mathrm{CO}_{2}$ and $\mathrm{CH}_{4}$ production in Alaskan permafrost peats, Glob. Change Biol., 20, 2674-2686, doi:10.1111/gcb.12572, 2014.

Treat, C. C., Natali, S. M., Ernakovich, J., Iversen, C. M., Lupascu, M., McGuire, A. D., Norby, R. J., Chowdhury, T. R., Richter, A., Šantrůčková, H., Schädel, C., Schuur, E. A. G., Sloan, V. L., Turetsky, M. R., and Waldrop, M. P.: A pan-Arctic synthesis of $\mathrm{CH}_{4}$ and $\mathrm{CO}_{2}$ production from anoxic soil incubations, Glob. Change Biol., 21, 2787-2803, doi:10.1111/gcb.12875, 2015.

Treseder, K. K.: Nitrogen additions and microbial biomass: a meta-analysis of ecosystem studies, Ecol. Lett., 11, 1111-1120, doi:10.1111/j.1461-0248.2008.01230.x, 2008.

Turetsky, M. R., Bond-Lamberty, B., Euskirchen, E. S., Talbot, J., Frolking, S. E., McGuire, A. D., and Tuittila, E.-S.: The resilience and functional role of moss in boreal and arctic ecosystems, New Phytol., 196, 49-67, doi:10.1111/j.14698137.2012.04254.x, 2012.

Waldrop, M. P., Wickland, K. P., White, R. I., Berhe, A. A., Harden, J. W., and Romanovsky, V. E.: Molecular investigations into a globally important carbon pool: permafrost-protected 
carbon in Alaskan soils, Glob. Change Biol., 16, 2543-2554, doi:10.1111/j.1365-2486.2009.02141.x, 2010.

Wan, H., Zhang, X., Zwiers, F. W., and Min, S.-K.: Attributing northern high-latitude precipitation change over the period 1966-2005 to human influence, Clim. Dynam., 45, 1713-1726, 10.1007/s00382-014-2423-y, 2015.

Watts, J. D., Kimball, J. S., Jones, L. A., Schroeder, R., and McDonald, K. C.: Satellite Microwave remote sensing of contrasting surface water inundation changes within the Arctic-Boreal Region, Remote Sens. Environ., 127, 223-236, doi:10.1016/j.rse.2012.09.003, 2012.

Weiss, N., Blok, D., Elberling, B., Hugelius, G., Jørgensen, C. J., Siewert, M. B., and Kuhry, P.: Thermokarst dynamics and soil organic matter characteristics controlling initial carbon release from permafrost soils in the Siberian Yedoma region, Sediment. Geol., 340, 38-48, doi:10.1016/j.sedgeo.2015.12.004, 2015.

Wendler, G. and Shulski, M.: A century of climate change for Fairbanks, Alaska, Arctic, 62, 295-300, 2009.

Wickland, K. P. and Neff, J. C.: Decomposition of soil organic matter from boreal black spruce forest: environmental and chemical controls, Biogeochemistry, 87, 29-47, doi:10.1007/s10533-0079166-3, 2008
Xue, K., Yuan, M. M., Shi, Z. J., Qin, Y., Deng, Y., Cheng, L., Wu, L., He, Z., Van Nostrand, J. D., Bracho, R., Natali, S. M., Schuur, E. A. G., Luo, C., Kostantinidis, K. T., Wang, Q., Cole, J. R., Tiedje, J. M., Luo, Y., and Zhou, J.: Tundra soil carbon is vulnerable to rapid microbial decomposition under climate warming, Nat. Clim. Change, 6, 595-600, doi:10.1038/nclimate2940, 2016.

Zhang, X., He, J., Zhang, J., Polyakov, I., Gerdes, R., Inoue, J., and $\mathrm{Wu}, \mathrm{P}$.: Enhanced poleward moisture transport and amplified northern high-latitude wetting trend, Nat. Clim. Change, 3, 47-51, doi:10.1038/nclimate1631, 2012.

Zhang, Y., Wolfe, S. A., Morse, P. D., Olthof, I., and Fraser, R H.: Spatiotemporal impacts of wildfire and climate warming on permafrost across a subarctic region, Canada, J. Geophys. Res.Earth, 120, 2338-2356, doi:10.1002/2015JF003679, 2015.

Zhou, L., Zhou, X., Zhang, B., Lu, M., Luo, Y., and Liu, L.: Different responses of soil respiration and its components to nitrogen addition among biomes: A meta-analysis, Glob. Change Biol., 20, 2332-2343, doi:10.1111/gcb.12490, 2014. 